\title{
A STUDY OF THE STANDARDIZATION OF DIGITALIS. II. THE RELATIONSHIP BETWEEN LABORATORY METHODS OF \\ ASSAY AND POTENCY AS DETERMINED BY EXPERI- \\ MENTAL CUMULATIVE POISONING AND \\ CLINICAL STANDARDIZATION
}

\author{
By H. B. vaN DYKE and R. C. LI \\ (From the Department of Pharmacology, Peiping Union Medical College, Peiping, China)
}

(Received for publication April 18, 1935)

It is commonly assumed that either frogs or cats may be used for the assay of digitalis, provided that suitable standards and experimental techniques are employed. Assay in frogs is the official method of the tenth revision of the United States Pharmacopoeia. The British Pharmacopoeia (1932) permits the use of both animals. Occasionally, however, there are encountered substances in digitalis leaf or glucosides from plants related pharmacologically to digitalis which are not of the same relative potency in frogs and in cats. The cumulation experiments in animals and the clinical experiments reported in this paper were undertaken to learn, in the case of two different samples of digitalis leaves, whether the results could be correlated with a method of assay.

\section{METHODS AND RESULTS OF ASSAY}

Seven different samples of powdered leaves of Digitalis purpurea were systematically investigated to ascertain their toxicity toward frogs (Rana nigromaculata) and mammals (cats and dogs). ${ }^{1}$ Extracts of each sample were made by using absolute alcohol in a Landsiedl extractor operated for eight hours (see Foster and van Dyke (1)). Two samples ( $D$ and $F$ ) were found to be equally toxic when administered to cats and dogs; in frogs, on the other hand, sample $D$ was significantly more toxic than sample $F$. Tinctures freshly prepared were used to learn their cumulative potency in dogs and their effectiveness in the clinic.

In the preparation of the tinctures for injection into frogs, alcohol was removed by the method described previously (1). Reasonably accurate measurements of potency were made by using, in most cases, groups of twenty to thirty frogs.

$1 \mathrm{We}$ are indebted to Mr. F. A. Upsher Smith for samples of leaves of Digitalis purpurea.
Eighteen hours after the injection of the alcoholfree extract into the ventral lymph sac, the mortality rate was observed. It was usually necessary to estimate the dose which would have killed fifty per cent of a group of frogs; for this purpose we employed the table given in the Brit-

TABLE I

The potency of leaf $F$ relative to leaf $D$ as determined by assay in frogs

\begin{tabular}{|c|c|c|c|c|}
\hline $\begin{array}{l}\text { Extraction } \\
\text { number }\end{array}$ & $\begin{array}{c}\text { Number } \\
\text { of } \\
\text { frogs } \\
\text { used }\end{array}$ & $\begin{array}{c}\text { Dose } \\
\text { killing } \\
\text { fifty } \\
\text { per cent }\end{array}$ & $\begin{array}{l}\text { Potency } \\
\text { of } F \\
\text { in terms } \\
\text { of } D^{*}\end{array}$ & $\begin{array}{l}\text { Potency } \\
\text { in terms } \\
\text { of U.S.P. } \\
\text { ouabain }\end{array}$ \\
\hline $1 \mathrm{D}$ & $\begin{array}{l}20 \\
20\end{array}$ & $\begin{array}{c}\text { mgm. per } \\
\text { kgm. } \\
209 \\
289\end{array}$ & 0.72 & $\times 10^{-4}$ \\
\hline $\begin{array}{ll}1 \mathrm{D} \\
1 \mathrm{~F}\end{array}$ & $\begin{array}{l}30 \\
30\end{array}$ & $\begin{array}{l}215 \\
333\end{array}$ & 0.65 & \\
\hline $2 \mathrm{D}$ & $\begin{array}{l}30 \\
30\end{array}$ & $\begin{array}{l}216 \\
370\end{array}$ & 0.58 & \\
\hline $\begin{array}{l}3 \mathrm{D} \\
3 \mathrm{~F}\end{array}$ & $\begin{array}{l}30 \\
30\end{array}$ & $\begin{array}{l}230 \\
345\end{array}$ & 0.67 & \\
\hline $\begin{array}{r}6 \mathrm{D} \\
-\quad 6 \mathrm{~F}\end{array}$ & $\begin{array}{l}15 \\
15\end{array}$ & $\begin{array}{l}230 \\
357\end{array}$ & 0.64 & \\
\hline $\begin{array}{c}11 \mathrm{D} \\
11 \mathrm{~F} \\
\text { Ouabain }\end{array}$ & $\begin{array}{l}20 \\
20 \\
20\end{array}$ & $\begin{array}{r}360 \\
460 \\
0.240\end{array}$ & 0.78 & $\begin{array}{l}6.67 \\
5.22\end{array}$ \\
\hline $\begin{array}{c}11 \mathrm{D} \\
11 \mathrm{~F} \\
\text { Ouabain }\end{array}$ & $\begin{array}{l}20 \\
20 \\
20\end{array}$ & $\begin{array}{r}310 \\
445 \\
0.203\end{array}$ & 0.70 & $\begin{array}{l}6.55 \\
4.57\end{array}$ \\
\hline $\begin{array}{c}\text { Internat. S.P.† } \\
\text { Ouabain }\end{array}$ & $\begin{array}{l}20 \\
20\end{array}$ & $\begin{array}{c}270 \\
0.226\end{array}$ & & 8.38 \\
\hline $\begin{array}{c}\text { Internat. S.P. } \\
\text { Ouabain }\end{array}$ & $\begin{array}{l}30 \\
30\end{array}$ & $\begin{array}{r}255 \\
0.206\end{array}$ & & 8.08 \\
\hline $\begin{array}{c}\text { Internat. S.P. } \\
\text { Ouabain }\end{array}$ & $\begin{array}{l}40 \\
40\end{array}$ & $\begin{array}{r}311 \\
0.290\end{array}$ & & 9.33 \\
\hline
\end{tabular}

* Mean and standard error of mean potency of $F$ in terms of $D=0.68 \pm 0.024$.

$\dagger$ Internat. S.P. $=$ International standard of potency. 
ish Pharmacopoeia (1932). Preliminary experiments, which are not reported, were performed with batches of ten frogs each to learn the appropriate doses; this was necessary because of variations in susceptibility due to such factors as season and previous care. Complete assays of five different tinctures of each sample ( $D$ and $F$ ) were made. The mean and the standard error of the mean of all the measurements of the potency of leaf $\mathrm{F}$ in terms of leaf $\mathrm{D}$ were found to be $0.68 \pm 0.024$ (Table I). The results were suffciently consistent to justify the belief that leaf $\mathrm{F}$ ration of meat, bread, and vegetables, as well as the housing of the dogs, was controlled. Ordinarily it was possible to inject only four dogs daily: one pair received suitable doses of tincture $\mathrm{D}$ and the other of tincture $\mathrm{F}$. The tinctures were diluted with isotonic saline solution and thoroughly mixed just before intravenous injection (antebrachial, saphenous, or external jugular vein). No anesthetic was employed. It was not found feasible to make electrocardiograms routinely; the respiratory rate, heart rate, and peculiarities of cardiac rhythm, as well as the presence or ab-

TABLE II

The potency of leaf $F$ relative to leaf $D$ measured in mammals

\begin{tabular}{|c|c|c|c|c|c|c|c|}
\hline \multirow[b]{2}{*}{ Group } & \multirow[b]{2}{*}{ Preparation } & \multirow[b]{2}{*}{ Animal } & \multirow{2}{*}{$\begin{array}{c}\text { Number } \\
\text { used }\end{array}$} & \multirow{2}{*}{$\begin{array}{l}\text { Mean and standard error } \\
\text { of mean lethal dose }\end{array}$} & \multicolumn{3}{|c|}{ Potency } \\
\hline & & & & & Animal & $\begin{array}{c}\text { Of } \\
\text { prepara- } \\
\text { tion }\end{array}$ & In terms of \\
\hline $\begin{array}{l}1 \\
2 \\
3 \\
4 \\
5 \\
6 \\
7\end{array}$ & $\begin{array}{c}\text { Leaf D } \\
\text { Leaf D } \\
\text { Leaf F } \\
\text { Leaf F } \\
\text { U.S.P. ouabain } \\
\text { U.S.P. ouabain } \\
\text { Internat. S.P. }\end{array}$ & $\begin{array}{l}\text { Cat } \\
\text { Dog } \\
\text { Cat } \\
\text { Dog } \\
\text { Cat } \\
\text { Dog } \\
\text { Cat }\end{array}$ & $\begin{array}{r}10 \\
9 \\
10 \\
9 \\
10 \\
10 \\
7\end{array}$ & $\begin{array}{c}\text { mgm. per } \mathrm{kgm} . \\
70.2 \pm 4.71 \\
80.1 \pm 6.73 \\
67.7 \pm 5.41 \\
75.6 \pm 3.30 \\
0.0807 \pm 0.0053 \\
0.0843 \pm 0.0062 \\
56.6 \pm 3.21\end{array}$ & $\begin{array}{l}\text { Cat } \\
\text { Dog } \\
\text { Cat } \\
\text { Cat } \\
\text { Cat } \\
\text { Cat } \\
\text { Dog } \\
\text { Dog }\end{array}$ & $\begin{array}{l}\text { Leaf F } \\
\text { Leaf } F \\
\text { Leaf F } \\
\text { Leaf D } \\
\text { Leaf F } \\
\text { Leaf D } \\
\text { Leaf F } \\
\text { Leaf D }\end{array}$ & $\begin{array}{r}\text { Leaf D: } 1.04 \\
\text { Leaf D: } 1.06 \\
\text { Internat. S.P.: } 0.84 \\
\text { Internat. S.P.: } 0.81 \\
\text { Ouabain: } 1.12^{*} \\
\text { Ouabain: } 1.05^{*} \\
\text { Ouabain: } 1.19^{*} \\
\text { Ouabain: } 1.15^{*}\end{array}$ \\
\hline
\end{tabular}

$* \times 10^{-3}$.

had a potency about 70 per cent of that of leaf D in frogs.

All the mammalian (cats and dogs) assays were performed according to a modified Hatcher-technique similar to that of Wallace and van Dyke (2). The condition and previous care of the animals used, as well as the experiments themselves, were kept uniform. The assays were about equal (Table II). Leaf $F$ in fact appeared to be slightly more potent, although the difference is not significant. The probability that the lethal doses for cats would be lower than those for dogs is 0.25 both for. Groups 1 and 2 and Groups 3 and 4 . The potencies of leaves $D$ and $F$ in terms of U. S. P. ouabain and international standard powder were approximately the same (Table II).

\section{Cumulative poisoning in dogs}

The cumulative effects of tinctures of samples $\mathrm{D}$ and $\mathrm{F}$ were assayed in dogs (2). Only healthy dogs, of comparable weight, were selected. The sence of vomiting, salivation, and diarrhea, were however recorded daily before and one hour after injection.

In some of the hearts were found, at necropsy, several specimens of Dirofilaria immitis, but there was no evidence that the presence of these contributed to the death of animals. In six pairs no infection with filaria was present as ascertained by examination of blood smears and at necropsy (Table III, Groups 1 and 2). Seven pairs of animals, a fraction of which were filaria-infected, and six additional pairs, the group of filaria-free animals, comprise Groups 3 and 4 (Table III). No other abnormalities were found.

The animals were weighed once every 48 hours. There was progressive loss of weight averaging, at death, about 17 per cent.

If the mean survival periods of Groups 1 and 2 and 3 and 4 are compared (Table III), there is no evidence that leaf $D$ differs significantly from leaf $F$. There were also no apparent differences 
TABLE III

Cumulative poisoning by tinctures of leaves $D$ and $F$. Thirty-five per cent of a lethal dose was administered daily to each dog

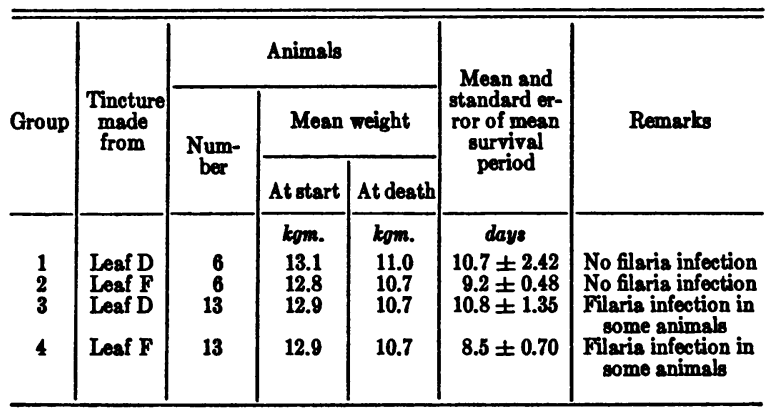

in the effects of the two samples on the cardiac rate and rhythm. The probability that similar differences in the mean survival period would be encountered by chance is 0.56 for Groups 1 and 2, and 0.15 for Groups 3 and 4 . It may therefore be concluded that the potencies of these tinctures (when used as cumulative poisons) were estimated more accurately by assay in cats and dogs than in frogs. It is of interest, but of doubtful significance, that sample $F$, although much less potent in frogs, nevertheless appeared equal or slightly more potent in cats and dogs when assayed not only by acute experiment but also by the cumulation method.

\section{Clinical measurements of the potency of the tinctures}

In a clinical assay it was possible to distinguish among three strengths of the same tincture, the relative potencies of which were $75: 100: 125$. Were the frog method of assay to give values parallel with those found in the clinic, leaf $F$ should turn out, in the clinic, to have only seventy per cent of the strength of leaf D-the relation actually found in frogs. In mammals, the two leaves were in fact equal.

For comparison with the assays in animals, the electrocardiograms of individuals, both normal and subject to cardiovascular diseases, were studied. All the subjects except 14 and 19 received courses of treatment with both tinctures

TABLE IV

Electrocardiographic measurements and constant " $K$ " before and after tinctures of leaves $D$ and $F$

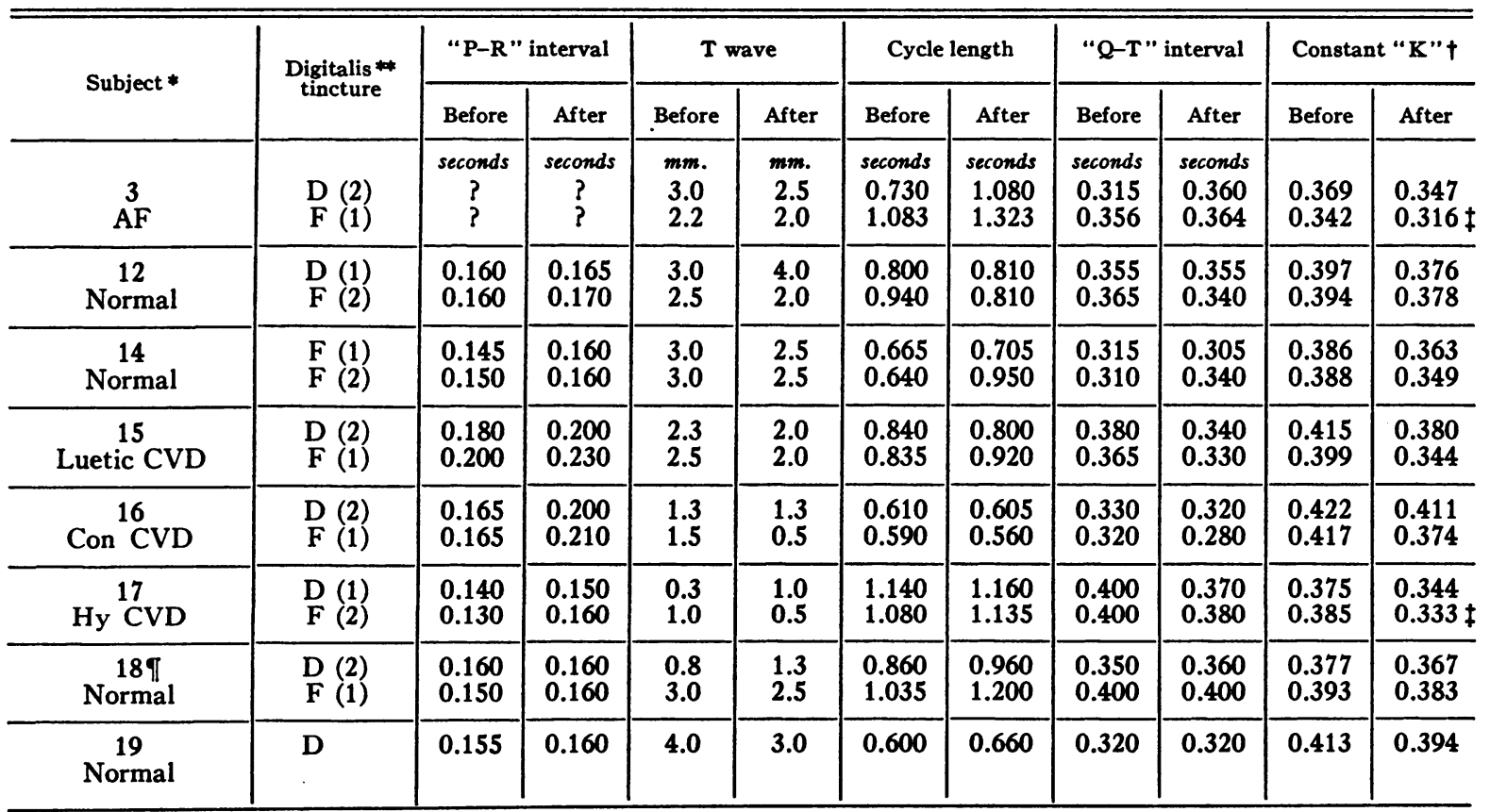

* "AF" is auricular fibrillation; "CVD" is cardiovascular disease; "Con" is congenital; "Hy" is hypertensive.

** The numbers in parentheses indicate the order of administration of the tinctures.

+ " $K$ " is "Q-T" interval divided by square root of cycle length.

$\ddagger$ Marked nausea.

T Only 0.8 proper dose of each tincture. 
(Tables IV and V). Because of a misunderstanding Subject 3 was given 0.3 gram of digitalis leaf ten days before tincture $\mathrm{F}$ but in all probability without appreciably affecting the result. The average shortening of the constant " $\mathrm{K}$ " (=Q-T interval/ $\sqrt{\text { cycle length })}$ was greater after taking tincture $F$, although it was consistently weaker by frog assay. The mean degree of shortening of " $K$ " and the standard error of the mean were $0.023 \pm 0.0056$ for tincture $\mathrm{D}$ and $0.035 \pm 0.0099$ for tincture $\mathrm{F}$. The difference between the means is not statistically significant. In dogs also tincture $\mathrm{F}$ appeared to be somewhat the stronger.

TABLE $\mathrm{V}$

Constant " $K$ " before and after tinctures of leaves $D$ and $F$

\begin{tabular}{c|c|c|c|c|c|c}
\hline \hline & \multicolumn{3}{|c|}{ Tincture D } & \multicolumn{3}{|c}{ Tincture F } \\
\cline { 3 - 7 } $\begin{array}{c}\text { Sub- } \\
\text { ject }\end{array}$ & Before & After & $\begin{array}{c}\text { Dif- } \\
\text { fer- } \\
\text { ence }\end{array}$ & Before & After & $\begin{array}{l}\text { Dif- } \\
\text { fer- } \\
\text { ence }\end{array}$ \\
\hline 3 & 0.37 & 0.35 & 0.02 & 0.34 & 0.32 & $0.02 \dagger$ \\
12 & 0.40 & 0.38 & 0.02 & 0.39 & 0.38 & 0.01 \\
15 & 0.42 & 0.38 & 0.04 & 0.40 & 0.34 & 0.06 \\
16 & 0.42 & 0.41 & 0.01 & 0.42 & 0.37 & 0.05 \\
17 & 0.38 & 0.34 & 0.04 & 0.39 & 0.33 & $0.06 \dagger$ \\
$18^{*}$ & 0.38 & 0.37 & 0.01 & 0.39 & 0.38 & 0.01 \\
\hline Sum & & & 0.14 & & & 0.21 \\
\hline 14 & & & & 0.39 & 0.36 & 0.03 \\
14 & 0.41 & 0.39 & 0.02 & 0.39 & 0.35 & 0.04 \\
19 & 0.45 & & \\
\hline
\end{tabular}

* Only 0.8 proper dose. $†$ Marked nausea.

\section{DISCUSSION}

The results of this investigation do not justify the generalization that assay of all or most samples of digitalis can be performed more usefully in cats or dogs than in frogs. More data with other samples are required. Our data offer support, however, for this generalization. Tinctures made of leaf $F$ were significantly weaker by frog assay than those made of leaf $D$. On the other hand in the mammalian assays, in the clinical tests, and in the cumulation experiments in dogs, they were all equally potent. Tinctures of leaf $F$ appeared in fact somewhat stronger than D-tinctures in mammalian experiments, although our data on this point are inconclusive.

$A$ reason for the different results with $F$ and
D may be due to a higher concentration of genins and a lower concentration of glucosides in leaf $\mathrm{F}$. It appears to be the general conclusion $(4,6)$ that the genins are less potent (one-third to onefifth) in frogs than the corresponding glucosides but have approximately equal strength in mammals (cats). Gröber (5) has come to a different conclusion, however; in frogs he thinks they (genins and glucosides) are equal, but in rabbits the genins about a third as powerful. It seems likely, furthermore, that genins are more loosely bound to cardiac muscle than are glucosides ( 7 , 8) and also more easily excreted. The inference would be natural therefore that if the F-leaves were richer in genins they would be weaker clinically and in cumulation experiments than the Dleaves. But F-leaves appear on the contrary to be as potent as D-leaves; sometimes indeed more potent.

In the case of the glucoside scillonin, Wallace and van Dyke (2) found that slight cumulative poisoning was associated with a relatively low acute toxicity in frogs and a high acute toxicity in cats and dogs. These findings obviously are different from those sometimes encountered in similar experiments with digitalis tinctures.

\section{SUM MARY}

Two samples of leaf of Digitalis purpurea were found to be equally potent in mammals (cats and dogs) but to differ significantly in potency as measured by assay in frogs. They were also compared by means of cumulation experiments in dogs and by a satisfactory method of clinical assay.

The cumulation experiments in dogs (Table III) and the clinical assays (Tables IV and V) were in agreement with the assays in mammals (Table II).

\section{BIBLIOGRAPHY}

1. Foster, R. H. K., and van Dyke, H. B., The effect of aging upon the potency of digitalis tinctures. $\mathrm{J}$. Am. Pharm. A., 1933, 22, 381.

2. Wallace, E. W., and van Dyke, H. B., Cumulative poisoning by squill derivatives and by ouabain. J. Pharm. and Exper. Therap., 1933, 48, 430.

3. Dieuaide, F. R., Tung, C. L., and Bien, C. W., A study of the standardization of digitalis. I. A method for clinical standardization. J. Clin. Invest., 1935, 14, 725. 
4. Straub, Walther, Chemischer Bau und pharmakologische Wirksamkeit in der Digitalisgruppe. Biochem. Ztschr., 1916, 75, 132.

5. Gröber, A., Uber Strophanthidin. Arch. f. exper. Path. u. Pharmakol., 1913, 72, 317.

6. Fromherz, K., and Welsch, A., Vergleich der Toxizität verschiedener herzwirksamer Reinsubstanzen und Fraktionen aus Digitalis purpurea für den Frosch und die Katze bei verschiedenen Applikations- bedingungen. Arch. f. exper. Path. u. Pharmakol., 1931, 161, 266.

7. Cloetta, Max, The biochemical action of digitalis. J. A. M. A., 1929, 93, 1462.

8. Weese, H., Digitalisverbrauch und Digitaliswirkung im Warmblüter. III. Mit. Zur Entstehung der Kumulation. Arch. f. exper. Path. u. Pharmakol., 1930, 150, 14. 